\title{
Effects of Appeal Type and Audience Gender on Perceptions of the Pope's Credibility
}

\author{
Jae-woongYoo \\ Professor. Department of Public Relations and Design \\ Eulji University, Seongnam, Korea \\ 461-713, 212 Yangji-dong, Sujeong-gu, Seongnam-si \\ Gyeonggi-do, Korea \\ Wan Soo Lee \\ Professor. Division of Media and Communication \\ Dongseo University, Busan \\ Korea/Corresponding Author \\ Yun-Kyoung Cho \\ Assistant Professor. College of Liberal Arts \\ Gachon University, Seongnam, Korea \\ 13120, 1342 Seongnamdaero, Sujeong-gu, Seongnam-si \\ Gyeonggi-do, Korea
}

\begin{abstract}
This study used an online experimental survey to examine the effects of appeal type (rational vs. emotional) and audience gender (male vs. female) on perceptions of credibility in messages by Pope Francis. The results showed no statistically significant differences between rational and emotional appeals in terms of effects on the Pope's credibility by message type, although female respondents were found to have stronger perceptions of the Pope's credibility than male respondents to a statistically significant degree. Examination of interaction effects on the Pope's perceived credibility from message type and respondent gender showed a statistically significant main effect difference according to gender, but no significant difference by appeal type, and no significant difference was observed in terms of interaction effects. Theoretical and managerial implications as well as directions for future research are discussed.
\end{abstract}

Keywords: Pope, appeal type, emotional appeal, rational appeal, credibility

The purpose of this study was to examine the effects on Pope Francis's credibility from his messages as the chief spiritual leader of the Roman Catholic Church. In focusing on a religious leader as a celebrity, the study differs from previous research on celebrities, which has tended to focus on the popular appeal of film actors and sports stars. Previous studies in areas involving active research on celebrity effects, including marketing and advertising, show two major trends. The first concerns observed effects on audience attitudes and behavior patterns toward products with advertising messages that employ celebrity spokespeople (e.g., Amos, Holmes,\& Strutton, 2008; Mishra \& Mishra, 2014; Roozen\&Claeys, 2010). The other concerns explorations of the factors accounting for the effects observed with these celebrities (e.g., Erdogan, 1999; McCracken,1989; Ohanian, 1991; Yoo \& Jin, 2015).

As a public figures whose every move is scrutinized by the media and who enjoys name recognition and trust around the world, the Pope would be expected to exhibit substantial effects not only with Catholics but with the general public as well. At the same time, religion contrasts with ordinary product purchasing patterns in being an issue of spiritual faith, with a diverse range of factors influencing related decisions. For this reason, the current study, ahead of any examination of the effect of papal messages on audience attitudes or behavioral intentions vis-à-vis Catholicism, will focus first on the Pope's credibility as arguably the basic factor in his social influence. To this end, it will apply the source attractiveness and source models, which were developed to explore the factors responsible for celebrity effects, as well as source model combining the two.

\section{Literature Review}

The dictionary definition of "celebrity" is "a famous person" or "the state of being well known". The meaning of the word changes when it is applied in different contexts; for instance, in advertising, a celebrity is defined as "an individual who is known to the public (i.e., actor, sports figure, entertainer, etc.) for his or her achievements in areas 
other than that of the product class endorsed" (Friedman \&Friedman, 1979; Kamins, Brand, Hoeke,\&Moe, 1989).While the Pope may differ in some respects from celebrities as understood from a marketing perspective, he exercises tremendous influence and draws public attention in as wide a range of areas as any other celebrity. His every action receives close media attention, and many express profound interest in his words and actions, regardless of their own religious affiliation.

\section{Papal message and appeal types}

While the Pope exercises influence in various ways, this study will focus on papal messages. Message is a key aspect of communication. Advancements and specialization in the field of message research have resulted in various studies aimed at classifying appeal types and maximizing appeal effects.

Two common approaches to classifying message type in research on message have been to distinguish between verbal and nonverbal communication (e.g., Brooks, 2011; Grabe \& Bucy, 2009; Koppensteiner \& Grammer, 2010; Stewart \& Dowe, 2013) or between rational (informational) and emotional messages (e.g., Claeys \& Cauberghe, 2014; Leonidou \& Leonidou, 2009; Moon \& Rhee, 2012; Mortimer \& Grierson, 2010). The former has been applied chiefly in various studies from the fields of political science and political psychology, while the latter is an active area of research in the fields of marketing and communication.

Even within marketing and communications, scholars differ in their definitions of what exactly is meant by a "rational" or "emotional" message. According to Leonidou andLeonidou (2009), rational appeals stimulate a logical thinking process in receivers of themessage, putting them in a position to clearly measure the advantages (andsometimes the disadvantages) of the product advertised(Churchill \& Peter, 1998). In contrast,the stimulating mechanism of emotional appeals centers on creating a state ofheightened psychological arousal, whereby the individual becomes alertand prepared to take certain actions (Hawkins, Best,\& Coney, 2003).Rational appeals refer mainly to practical, functional consumer needs,as opposed to emotional appeals that are directed mainly to psychologicalaspects of these needs (Bovée \& Arens, 1992).Moon and Rhee (2012) argue that rational appeals focus on providing concrete and clear information about the given topic in order to change the recipient's beliefs by relying on arguments or reason. On the other hand, in persuading recipients, emotion-centered appeals focus on presenting various images and words that stimulate positive or negative emotions and atmosphere about the given topic.

Similarly, scholars differ in their views on the communication effects associated with different appeal types. Some argue that rational appeals elicit more positive reactions (e.g., Aaker \& Norris, 1982; Stafford \& Day, 1995), while others claim emotional appeals to be more effective (e.g., Unwin, 1975). At the same time, an examination of previous research suggests that rational appeals are primarily a means of influencing audiences by way of logical thinking processes, whereas emotional appeals involve creating a state of heightened psychological arousal, and that emotional appeals are often found to be more effectivein attracting consumer attention when compared to rational appeals (Biener et al., 2008; Heath, 2006; Lim \& Ahmed, 2016; Pringle \& Field, 2008).

While the issue remains the subject of ongoing debate in the field of advertising studies, the recent trend has generally been to argue that the appeal type with the greatest effect depends on a wide range of variables, including the targets, the nature of the product, congruence between message and product, and audience characteristics (Albers-Miller \& Stafford, 1999; Shavitt, 1992).

\section{Celebrity Influence Attribute Model}

The source attractiveness model and source credibility model may be seen as the chief theoretical models in marketing and communication to explain the influence of celebrities (Erdogan, 1999). The source attractiveness model maintains that celebrities possess a distinctive form of appeal that sets them apart from ordinary people, and that this appeal is the chief factor through which they exert influence. It argues that a message's effectiveness relies on the "familiarity," "likability," and/or "similarity" of the source (McGuire, 1985). The source attractive model was met with numerous criticisms upon its presentation; for instance, examples have been noted of celebrities exerting large influence socially despite not being perceived as appealing. It was to account for this phenomenon that the source credibility model was presented (Ohanian, 19990), with a focus on the expertness and/or trustworthiness of a given celebrity. The source credibility model analyzes the factors influencing the perceived credibility of the communicator. The model contends that a message's effectiveness depends on the "expertness" and "trustworthiness" of the source (Ohanian, 1991). Expertise, which represents the extent to which a communicator is perceived to be a source of valid assertions (Hovland \& Weiss, 1951), is a factor that arises from knowledge, experience, or training that the spokesperson possesses in the relevant field (Erdogan, 1999), while trustworthiness refers to the audience's confidence in the source's ability to provide information in an objective and honest manner (Erdogan, 1999). 
Despite their respective merits, the source credibility model and source attractive model have revealed limitations in terms of emphasizing only one aspect each. Combining these two models (i.e., source attractiveness and source credibility), McCracken (1989) suggested a so-called "source model" (p. 311) that includes the key elements of expertise, trustworthiness, and attractiveness.Yoo and $\operatorname{Jin}(2013,2015)$ echoed Ohanian (1991) in defining the concept of source credibility as characteristics of a communicator that account for the receiver's acceptance of the message; viewing attractiveness as an attribute that could be included within the credibility concept alongside expertise and trustworthiness, they defined credibility as a concept encompassing these three aspects.

Based on this understanding, the current study has the primary goal of a comparative analysis on the effects of papal message type (rational vs. emotional) on audience perceptions of the Pope's own credibility. Because the effects of a communicative message may differ according to audience characteristics (Albers-Miller \& Stafford, 1999; Shavitt, 1992), it further considers possible interaction effects from audience gender. The following research questions were developed accordingly:

RQ1: What differences are observed in the effects of a Papal message on audience perceptions of the Pope's credibility by appeal type (rational vs. emotional)?

RQ2: What differences are observed in effects on audience perceptions of the Pope's credibility by audience gender?

RQ3: What interaction effects are observed in the Pope's perceived credibility according to message type (rational vs. emotional) and audience gender (male vs. female)?

\section{Method}

\section{Stimuli and pretest}

To ensure ecological validity, the current Pope (Francis) was selected for examination of the effects of papal messages. Two forms of experimental stimuli with papal messages were developed in the form of mock newspaper articles respectively showing rational and emotional appeals. Rational and emotional appeals for the experimental stimuli were based on previous studies on message effects (e.g.,Claeys \& Cauberghe, 2014; Moon \& Rhee, 2012). The rational appeal stimulus focused on communication of clear information, while the emotional appeal stimulus was developed to include words or images designed to evoke emotions. Because the focus of the study was a religious leader, the rational appeal stimulus was developed with a display characterized by no or obscured movement in the upper face, as per the neutral photograph guidelines suggested by Stewart and Dowe (2013). In this case, a photograph of the Pope presiding calmly over a mass was accompanied by a message calling for peace and reconciliation on the Korean Peninsula. In contrast, the emotional appeal stimulus consisted of an article with a photograph of the Pope kissing and stroking the head of a disabled person while visiting a community of persons with disabilities, a design that was intended to emphasize his gentleness and benevolence. Articles were standardized in terms of article size, title size, number of words, photo size and location, and layout.

To test the suitability of the two stimuli, a pretest was given in which 33 ordinary respondents were asked to rate them on a seven-point Likert scale for three categories (positive feeling, happiness, and appeasement) as per Dillard \& Wilson (1993) and Stewart (2010). The results showed a statistically significant difference $(p<.001)$ between the emotional stimulus (Mean=5.45, $S D=1.35$ ) and the rational stimulus (Mean=4.38, $S D=1.26$ ).

\section{Data collection}

An online survey using the experiment treatment was carried out in January 2015 with a final sample size of 240 people (120 for each cell). A professional online survey agency was employed for sampling. The company that performed the study is an online research firm with a 690,000-member panel. For the procedure, a survey questionnaire was mailed electronically to randomly selected panel participants who had taken part in at least one other online survey within one year of the mailing date. Based on the company's recent average rate of response, email messages containing a link to the survey were sent to 5,233 panelists, among whom 2,342 read it and 1,228 took part in the panel.

508 responses werediscarded as exceeding the quota, while another 480 were screened out for a perceived lack of due care (such as the submission of identical responses for multiple items), giving a pool of sample data for 240 participants, or 120 per cell.

To ensure homogeneity among cells, each was chosen to represent the gender and age distribution reported by the National Statistical Office of Korea in 2010. The total pool consisted of 124 males (51.7\%) and 116 females (48.3\%) with $19.2 \%$ participants aged $20-29,20.8 \%$ aged $30-39,30 \%$ aged $40-49$, and $30 \%$ aged $50-59$.

\section{Measures}




\section{The Pope's credibility}

Perceptions of the Pope's credibility were measured with 15items on a nine-point Likert scale examining the three dimensions used by Ohanian $(1990,1991)$ to measure celebrity credibility, namely perceived attractiveness, trustworthiness, and expertise, with items adjusted to suit the subject of the survey. Items on the attractiveness scale consisted of the modifiers "attractive," "classy," "beautiful," "elegant," and "appealing" $(M=6.48, S D=1.64$, Cronbach's $\alpha=.96)$. Trustworthiness was measured through the modifiers "dependable," "honest," "reliable," "sincere," and "trustworthy" $(M=6.95, S D=1.60$, Cronbach's $\alpha=.98)$. The expertise scale included the descriptors "expert," "experienced," "knowledgeable," "qualified," and "skilled" ( $M=6.75, S D=1.58$, Cronbach's $\alpha=.97)$.

\section{Manipulation check}

A recheck was performed to ensure that the two stimuli featuring Papal messages with different appeal types were handled appropriately. The three items from the preliminary survey (positive feeling, happiness, and appeasement) were measured again on a nine-point Likert scale as in Dillard \& Wilson (1993) and Stewart (2010). The results once again showed a statistically significant difference $(t=-3.50, d f=238, p<.01)$ for emotional values between the rational appeal group $(M=5.98, S D=1.59)$ and emotional appeal group $(M=6.69, S D=1.54)$. It was therefore concluded that the rational and emotional stimuli had been developed appropriately.

\section{Results}

To analyze the effects of appeal type on Pope's credibility (RQ1), a T-test was performed. As Table 1 shows, the difference between the "rational message" $(M=6.70, S D=1.66)$ and "emotional message" $(M=6.94, S D=1.52)$ types was not statistically significant, although the emotional message resulted in a higher rating than the rational message. A second T-test was performed to analyze effects according to gender on perceptions of the Pope's credibility (RQ2). As Table 1 shows, the difference between male respondents $(M=6.44, S D=1.62)$ and female respondents $(M=7.22$, $S D=1.47$ ) was statistically significant.

Table 1. Differences in the Pope's Perceived Credibility by Message Type and Audience Gender

\begin{tabular}{|c|c|c|c|c|c|c|c|}
\hline Items & & & & & & Mean & \\
\hline $\begin{array}{l}\text { Dependent } \\
\text { Variable }\end{array}$ & $\begin{array}{l}\text { Appeal type \& } \\
\text { Gender }\end{array}$ & $N$ & $M$ & $S D$ & $t$ & $\begin{array}{l}\text { Difference } \\
{[(2)-(1)]}\end{array}$ & Sig. \\
\hline \multirow{3}{*}{$\begin{array}{l}\text { Pope's } \\
\text { credibility }\end{array}$} & Rational (1) & 120 & 6.70 & 1.66 & 1.118 & 0.24 & .236 \\
\hline & Male (1) & 124 & 6.44 & 1.62 & \multirow[t]{2}{*}{3.923} & \multirow{2}{*}{0.78} & \multirow{2}{*}{$.000 * * *$} \\
\hline & Female (2) & 116 & 7.22 & 1.47 & & & \\
\hline
\end{tabular}

$* p<.05 * * p<.01 * * * p<.001$

A MANOVA analysis was conducted to examine interaction effects on the Pope's perceived credibility by message type and respondent gender (RQ3). As shown in Table 2, a statistical difference (.000) was observed according to gender in the main effect, while the difference by appeal type was not statistically significant different (.221). Similarly, the difference in the interaction effect was not statistically significant (.858).

Table 2. Interaction Effect of Papal Message Type and Audience Gender on the Pope's Perceived Credibility

\begin{tabular}{|c|c|c|c|c|c|c|}
\hline $\begin{array}{l}\text { Dependent } \\
\text { variables }\end{array}$ & Source & $\begin{array}{l}\text { Types III Sum } \\
\text { Of Squares }\end{array}$ & $d f$ & $\begin{array}{l}\text { Mean } \\
\text { Square }\end{array}$ & $F$ & Sig. \\
\hline \multirow{7}{*}{$\begin{array}{l}\text { Pope's } \\
\text { credibility }\end{array}$} & Corrected Model & 40.632 & 3 & 13.544 & 5.628 & $.001 * * *$ \\
\hline & Intercept & 11186.138 & 1 & 11186.138 & 4647.953 & $.000 * * *$ \\
\hline & Message type & 3.616 & 1 & 3.616 & 1.503 & .221 \\
\hline & Gender & 36.969 & 1 & 36.969 & 15.361 & $.000 * * *$ \\
\hline & Message*Gender & .078 & 1 & .078 & .032 & .858 \\
\hline & Error & 567.977 & 236 & 2.407 & & \\
\hline & Total & 11764.311 & 240 & & & \\
\hline
\end{tabular}

\section{Discussion and conclusion}

The results of this study have a number of theoretical implications. First, it may be said to possess primary significance in expanding the scope of celebrity research from its hitherto focus on popular stars to include religious leaders and in examining the effects of messages from religious leaders and characteristics of the audience. A second, potentially 
more concrete implication in terms of the effects of message type on the Pope's credibility is the fact that while rational appeals had a slightly stronger effect than emotional appeals, the difference was not statistically significant, which may be said to suggest that Papal messages different in character from the messages of more typical celebrities. In other words, the effects of messages from a respected religious leader such as the Pope may be attributed to a more general sense of awe at a figure perceived as relaying messages from God. This implies that the religious realm differs from marketing or general communication in terms of the relative unimportance of the message type. A third implication concerns the effects of audience gender on the Pope's perceived credibility. The fact that female respondents showed a stronger response than male ones to a statistically significant degree echoes findings indicating that women generally have stronger religious faith than men, as suggested by 2015 Korean Catholic Church statistics showing women accounting for $58 \%$ of members to men's $42 \%$. The relationship between gender and the Pope's perceived credibility may be seen as indicating that audience characteristics such as gender exert a more significant influence than message type in the religious domain.

In terms of practical implications, the findings suggest that the form of message is of lesser importance in enhancing the audience persuasion effects of communication by respected religious leaders such as the Pope. In other words, they indicate that the content delivered in the message is more important than the form of appeal. The fact that female respondents showed a stronger response than male ones in terms of perceptions of the Pope's credibility suggests that customized messages reflecting audience gender composition were of greater significance in achieving audience persuasion. In view of the struggles that many religious faiths have encountered in expanding their numbers amid an overall global trend of declining membership in Catholicism and other religions, the findings may be seen as indicating where the focus should lie when using religious leaders as part of a strategy to increase religious membership.

Although this study offers numerous theoretical and practical implications, it also contains a number of limitations. First, it adopted a format in which a single example of papal message type was presented before audience responses were examined. Future studies may contribute to generalization of the findings by presenting examples from other fields or multiple stimuli before analyzing findings. Second, this study applied the typical concepts of rational and emotional appeals in its examination of their differences. As many studies on the persuasiveness of messages have involved the elaboration likelihood model (ELM), interesting implications may be arrived at in future studies by considering not only message type effects but also what routes audiences tend to rely on in receiving messages. Third, while this study focused on papal messages and the Pope's credibility, future studies should adopt a more in-depth analytical framework in considering the effects of such messages on attitudes and behavioral intensions toward the Catholic faith represented by the Pope. Fourth, the respondents in this study were citizens of South Korea. Future studies should examine responses from other countries, including the U.S. and the nations of Europe and elsewhere in Asia, for a comparative examination of audience responses.

\section{References}

Aaker, D., \& Norris, D. (1982). Characteristics of TV commercials perceived asinformative.Journal of Advertising Research, 22(2), 61-70.

Albers-Miller, N. \& Stafford, M. (1999). An international analysis of emotional and rational appeals in services vs. goods advertising. Journal of Consumer Marketing 16(1), 42-57.http://dx.doi.org/10.1108/07363769910250769

Amos, C., Holms, G., \& Strutton, D. (2008). Exploring the relationship between celebrity endorser effects and advertising effectiveness. International Journal of Advertising, 27(2), 209-234. http://dx.doi.org.access.hanyang.ac.kr/10.1080/02650487.2008.11073052

Biener, L., Wakefield, M., Shiner, C. M., \& Siegel, M. (2008). How broadcast volume and emotional contentaffect youth recall of anti-tobacco advertising. American Journal of Preventive Medicine, 35, 1419.http://dx.doi.org/10.1016/j.amepre.2008.03.018

Bov'ee, C. L., \& Arens, W. F. (1992). Contemporary advertising. Homewood, IL: R.D. Irwin.

Brooks, D. J. (2011). Testing the double standard for candidate emotionality: Voter reactions to the tears and anger of male and female politicians. Journal of Politics, 73(2), 597-615.http://dx.doi.org/10.1017/S0022381611000053

Churchill Jr., G. A., \& Peter, J. P. (1998). Marketing: Creating value for customers(2nd ed.). Boston: Irwin/McGraw Hill

Claeys, A. S. \& Cauberghe, V. (2014). What makes crisis response strategies work?The impact of crisis involvement and message framing. Journal of BusinessResearch,67(2), 189.http://dx.doi.org/10.1016/j.jbusres.2012.10.005

Dillard,J. P., \& Wilson, B. J. (1993). Communication and affect: Thoughts feeling, and issues for the future. Communication Research, 20(5). 637-646.http://dx.doi.org/10.1177/009365093020005001 
Erdogan, B. Z. (1999). Celebrity endorsement: A literature review. Journal of Marketing Management, 15(4), 291314.http://dx.doi.org/10.1362/026725799784870379

Friedman, H. H., \& Friedman, L. (1979). Endorse effectiveness by product type. Journal of Advertising Research, 19(5), 63-71.

Grabe, M. E., \& Bucy, E. P. (2009). Image bite politics: News and the visual framing of elections. Oxford, UK and NewYork: Oxford University Press.

Hawkins, D. I., Best, R. J., \& Coney, K. A. (2003). Consumer behavior: Buildingmarketing strategy. New York: McGraw Hill.

Heath, R. G. (2006). The influence of emotional content in TV advertising on levels of attention. Bath:University of Bath.

Hovland, C. I., \& Weiss, W. (1951). The influence of source credibility on communication effectiveness. Public Opinion Quarterly, 15, 635-650.http://dx.doi.org/10.1086/266350

Kamins, M. A., Brand, M. J., Hoeke, S. A., \& Moe, J. C. (1989). Two-sided versus one-sided celebrity endorsements: The impact on advertising effectiveness and credibility. Journal of Advertising, 18(2), 410.http://dx.doi.org/10.1080/00913367.1989.10673146

Koppensteiner, M., \& Grammer, K. (2010). Motion patterns in political speech and their influence on personality ratings. Journal of Research in Personality, 44, 374-379.http://dx.doi.org/10.1016/j.jrp.2010.04.002

Leonidou, L. C., \& Leonidou, C. N. (2009). Rational versus emotional appeals in newspaper advertising: Copy, art, and layout differences. Journal of Promotion Management, 15(4), 522-546. http://dx.doi.org/10.1080/10496490903281353

Lim, W. M., Teh, P.,\& Ahmed, P. K. (2016). It is notabout what you read, but how you read it: The effects of sequencing rational and emotionalmessages on corporate and product brand attitudes, Journal of Strategic Marketing, http://dx.doi.org/10.1080/0965254X.2016.1240216

McCracken, G. (1989). Who is the celebrity endorser? Cultural foundations of the endorsement process. Journal of Consumer Research, 16(3), 310-321.http://dx.doi.org/10.1086/209217

McGuire, W. J. (1985). Attitudes and attitude change. In L. Gardner and E. Aronson (Eds.), Handbook of Social Psychology (pp. 233-346). New York: Random House.

Mishra, A. A., \& Mishra, A. (2014). National vs. local celebrity endorsement and politics. International Journal of Politics, Culture, and Society, 27(4), 409-425.http://dx.doi.org/10.1007/s10767-014-9174-y

Moon, B. T. \& Rhee, Y. (2012). Message strategies and forgiveness during crisis:Effects of causal attributions and apology appeal types on forgiveness.Journalism \& Mass Communication Quarterly, 89(4), 677694.http://doi.org.ssl.access.hanyang.ac.kr/10.1177/1077699012455388

Mortimer, K., \& Grierson, S. (2010). The relationship between culture and advertising appeals for services. Journal of Marketing Communications, 16(3), 149-162.

Ohanian, R. (1990). Construction and validation of a scale to measure celebrity endorsers' perceived expertise, trustworthiness, and attractiveness. Journal of Advertising, 19(3), 3952.http://dx.doi.org.access.hanyang.ac.kr/10.1080/00913367.1990.10673191

Ohanian, R. (1991). The impact of celebrity spokesperson's perceived image on consumers' intention to purchase. Journal of Advertising Research, 31(1), 46-54.

Pringle, H., \& Field, P. (2008). Brand immortality: How brands can live long and prosper. London: Kogan.

Roozen, I., \& Claeys, C. (2010). The relative effectiveness of celebrity endorsement for print advertisement. Review of Business and Economics, 1, 76-89.

Shavitt, S. (1992). Evidence for predicting the effectiveness of value-expressive versusutilitarian appeals: A reply to Johar and Sirgy.Journal of Advertising, 21(June), 47-51.http://dx.doi.org/10.1080/00913367.1992.10673367

Stafford, M. R. \& Day, E. (1995). Retail services advertising: The effects of appeal, medium, and service. Journal of Advertising, 24(1), 57-71. http://dx.doi.org/10.1080/00913367.1995.10673468

Stewart, P. A.(2010). Presidential laugh lines Candidate display behavior and audience laughter in the 2008 primary debates. Politics and the Life Science, 29(2), 55-72.http://dx.doi.org/10.2990/29_2_55

Stewart, P. A., \&Dowe, P. K. (2013). Interpreting president Barack Obama's facial displays of emotion: Revisiting the Dartmouth Group. Political Psychology, 369385.http://onlinelibrary.wiley.com.access.hanyang.ac.kr/enhanced/exportCitation/doi/10.1111/pops.12004

Unwin, S. (1975). Customized communications - A concept for service advertising. Advertising Quarterly, 44, 28-30.

Yoo, J. W., \& Jin, Y. J. (2013). Effects of celebrity-organization congruence on audience attitudes, preferences, and credibility ratings for goodwill ambassadors. Asian Journal of Communication, 23(6), 620636.http://dx.doi.org/10.1080/01292986.2013.790912 
Yoo, J. W.,\& Jin, Y. J. (2015). The effects of leader image on national reputation: Influence of Chinese presidents Hu Jintao and Xi Jinping on Korean perceptions and attitudes toward China. Corporate Reputation Review, 18(1), 50-64. http://dx.doi.org/10.1057/crr.2014.20 